\title{
Evaluation of knowledge and application towards ergonomic principles among undergraduate dental students
}

\author{
A valiação do conhecimento e aplicação dos princípios ergonômicos entre alunos de graduação em \\ odontologia
}

Evaluación de conocimientos y aplicación de principios ergonómicos en estudiantes de odontología

de pregrado

Received: 10/08/2021 | Reviewed: 10/16/2021 | Accept: 10/25/2021| Published: 10/28/2021

Marcely Silva Araújo
ORCID: https://orcid.org/0000-0002-1811-2196
Universidade Federal do Maranhão, Brazil
E-mail: marcely.araujo@discente.ufma.br
Vandilson Pinheiro Rodrigues
ORCID: https://orcid.org/0000-0002-6785-7864
Universidade Federal do Maranhão Brazil
E-mail: vandilson.rodrigues@ufma.br
Rogério Vera Cruz Ferro Marques
ORCID: https://orcid.org/0000-0003-0726-516X
Faculdade Edufor, Brazil
E-mail rm20@ig.com.br
André Luis Costa Cantanhede
ORCID: https://orcid.org/0000-0001-5218-5746
Faculdade de Odontologia de Piracicaba, Brazil
E-mail ravenni@hotmail.com
Isabelle Aguiar Prado
ORCID: https://orcid.org/0000-0001-9970-7783
Universidade Federal do Maranhão, Brazil
E-mail: isabelle.prado@discente.ufma.br
Andréa Dias Neves Lago
ORCID: https://orcid.org/0000-0003-4303-6399
Universidade Federal do Maranhão, Brazil
E-mail adnlago@gmail.com
Guilherme Silva Furtado
ORCID: https://orcid.org/0000-0002-8796-1634
Universidade Federal do Maranhão, Brazil
E-mail gfurtado.ufma@gmail.com
Daniele Meira Conde Marques
ORCID: https://orcid.org/0000-0001-6378-0858
Universidade Federal do Maranhão, Brazil
E-mail daniele.conde@ufma.br

\begin{abstract}
This study evaluated the knowledge and application of ergonomic principles as well as manifestation of pain by dental students at the Federal University of Maranhão. Forty-four students answered a questionnaire on ergonomic principles. Photographs of the clinical rounds were performed to evaluate the postures adopted, without the students knowing the moment of photographic registration, avoiding that they modified their posture. The relationship between theoretical knowledge and the applicability of ergonomics in dental setting was evaluated. Data were analyzed using descriptive statistics. The Chi-square test analyzed the distribution of categorical variables among the evaluation instruments $(\alpha=$ $5 \%$ ). Most of the participants adopted a satisfactory posture and presented knowledge about ergonomic postures, however, one can observe the poor positioning of the eyes and spine. $75 \%$ of the patients experienced pain in the body, being the spine $(61.4 \%)$ and neck $(40.9 \%)$ the most affected sites. The sample evaluated had good knowledge on ergonomic principles, but these were not adopted entirety, which may have led to the onset of pain.
\end{abstract}

Keywords: Ergonomics; Dentistry; Worker's health.

\section{Resumo}

Este estudo avaliou o conhecimento e a aplicação dos princípios ergonômicos e também a manifestação da dor por alunos de odontologia da Universidade Federal do Maranhão. Quarenta e quatro alunos responderam a um questionário 
sobre princípios ergonômicos. Foram realizadas fotografias das rodadas clínicas para avaliação das posturas adotadas, sem que os alunos soubessem o momento do registro fotográfico, evitando que modificassem sua postura. A relação entre o conhecimento teórico e a aplicabilidade da ergonomia em consultório odontológico foi avaliada. Os dados foram analisados por meio de estatística descritiva. O teste Qui-quadrado analisou a distribuição das variáveis categóricas entre os instrumentos de avaliação $(\alpha=5 \%)$. A maioria dos participantes adotou postura satisfatória e apresentou conhecimento sobre posturas ergonômicas, porém, pode-se observar o mau posicionamento dos olhos e da coluna. $75 \%$ dos pacientes sentiram dores no corpo, sendo a coluna vertebral $(61,4 \%)$ e o pescoço $(40,9 \%)$ os locais mais acometidos. A amostra avaliada possuía bons conhecimentos sobre os princípios ergonômicos, mas estes não foram adotados na íntegra, o que pode ter ocasionado o aparecimento de dores.

Palavras-chave Ergonomia; Odontologia; Saúde do trabalhador.

\section{Resumen}

Este estudio evaluó el conocimiento y la aplicación de los principios ergonómicos y la manifestación del dolor por parte de estudiantes de odontología de la Universidad Federal de Maranhão. Cuarenta y cuatro estudiantes respondieron el cuestionario sobre principios ergonómicos. Se realizaron fotografías de las rondas clínicas para evaluar las posturas adoptadas, sin que los estudiantes supieran el momento del registro fotográfico, evitando que modificaran su postura. Se evaluó la relación entre los conocimientos teóricos y la aplicabilidad de la ergonomía en el ámbito odontológico. Los datos fueron analizados utilizando estadística descriptiva. La prueba de Chi-cuadrado analizó la distribución de variables categóricas entre los instrumentos de evaluación $(\alpha=5 \%)$. La mayoría de los participantes adoptaron la postura de alguien y presentaron conocimientos sobre ergonomía, sin embargo, se puede observar la mala posición de los ojos y la columna. El 75\% de los pacientes experimentaron dolor en el cuerpo, siendo la columna $(61,4 \%)$ y el cuello (40,9\%) los sitios más afectados. La muestra evaluada tenía un buen conocimiento de los principios ergonómicos, pero estos no fueron adoptados en su totalidad, lo que pudo haber provocado la aparición del dolor.

Palabras clave: Ergonomía; Odontología; Salud del trabajador.

\section{Introduction}

Ergonomics is the science that brings a set of multidisciplinary knowledge applied in the workplace organization and the elements which make up labour activities, with the objective of assuring a safe, healthy and comfortable environment and preventing work-related diseases by improving the effectiveness of the service (Gopinadh et al., 2013).

Ergonomic conditions should provide a work situation which does not harm the health of those who do so, allowing them to be able to exercise their tasks and avoid work-related hazards (Oliveira et al., 2018).

In dentistry, ergonomics aims to reduce physical and mental stress, to prevent dental practice diseases related, to seek greater productivity, with better quality of life, comfort for the professional and, consequently, for the patient (Kee \& Karwowski, 2007; Garcia, 2016; Sachdeva et al., 2020; Shobhana et al., 2020).

Although dentistry has evolved technologically in recent decades, there is a consensus on the lack of progress with regards to the professional's health (Ahearn et al., 2010). Nature of the dental profession and postures assumed by dentists during their work has an effect on their body (Sachdeva et al., 2020; Shobhana et al., 2020). The dentist acts repeatedly, performing clinically operational skills restricted to a small region as the oral cavity and requirements for precision in this region and the muscular exertion required in some dental procedures make these individuals very vulnerable to occupational risks (Garbin et al., 2011).

It is known that the prevalence of discomfort and musculoskeletal pain in dentists is higher than in the general population (Wilson et al., 2006; Michalak-turcotte, 2000; Shobhana et al., 2020), with neck, shoulders, upper limbs and, mainly, lower back the most sites being affected. These factors may result in the decline of the working production of the dental practitioners, with early withdrawal from work due to permanent or temporary disability (Hosseini et al., 2019; Saliba, et al., 2016; Evelyn \& Jain, 2020). Most of the time, musculoskeletal disorders are sluggish to emerge; consequently, professionals end up getting used to pain or discomfort, and forgetting to take care of his/her own health (Saliba, et al., 2016).

In order to prevent work-related illnesses, as well as providing greater comfort and health to the professionals and patients, the International Standards Organization (ISO) and the Fédération Dentaire Internacionale (FDI) have promoted a 
restructuring in order to standardize the daily work at the dental office, establishing ergonomic norms and guidelines, which should be adopted by dental professionals and academics (Garbin et al., 2011). The application of the principles of ergonomics to equipment and the workplace is an effective way to guarantee healthiness, safety, high performance, motivation and satisfaction in the dental set-up.

The acquisition of these knowledges must occur at any given moment of professional life, however, the earlier they are installed, greater will be the benefits, assimilation and incorporation, thus avoiding in the case of dental ergonomic posture, the formation of detrimental habits (Garcia et al., 2008; Kumar et al., 2012).

As dental students are also subject to occupational risks inherent to dental practice (Movahhed et al., 2013; Pejčić et al., 2020), researches on the knowledge and application of ergonomic principles by those individuals becomes relevant, aiming at prevention, awareness and early education, in order to take them to new postural conditions and better professional performance.

Facing the exposed, the objective of this study is to assess the knowledge on ergonomic principles, as well as to identify the difficulties of clinical posture during dental practice and painful manifestation by final-year dental students at a public dental school in Brazil.

\section{Methodology}

\subsection{Study design:}

This cross-sectional study was conducted at the dental clinics of the School of Dentistry of the Federal University of Maranhao from September to December 2017. Initially, the Research Ethics Committee of the University Hospital of the Federal University of Maranhao approved this study ( $\left.n^{\circ} 2,510,609\right)$.

The study population consisted of all last year undergraduated students of the School of Dentistry (in order to make the sample more homogeneous, as they have already studied Ergonomics and exercises similar clinical activities). A total of 44 students participated, whose Informed Consent was obtained.

Firstly, the students answered a questionnaire to evaluate their knowledge about ergonomic principles and painful manifestations. In addition, students were photographed during their clinical rounds to assess the application of ergonomic postures.

\subsection{Data collection:}

Participants answered a self-administered survey questionnaire with 14 objective questions regarding social data, painful manifestations and knowledge of ergonomic principles.

A pilot study was performed with students who did not make up the study sample, in order to assess the quality of the questionnaire. Questions that generated doubts were reformulated, until the questionnaire was fully validated.

\subsection{Photographic record:}

Photographs of the students during their routine dental procedures at the clinics were taken. Students were not informed when the photographs would be taken, thus preventing them from changing their posture, which allowed a reliable analysis of the positions adopted during the visits. Two previously calibrated evaluators analyzed the images independently.

For calibration, photographs of procedures performed by students who were not part of the study sample were taken and analyzed together by the evaluators, using the same assessment criteria that would be used in the study.

To analyze the photographs, a checklist-type evaluation system was used, according to the methodology adopted in other studies (Michalak-turcotte, 2000; Bendezú et al., 2006). The list contained nine items on ergonomic postures, related to the professional's positions and equipment used, following the specifications established by ISO (2006). 
For each item correctly performed by students, a 1 point value was assigned, as proposed by Garbin et al. (2011), with the following classification: 1 to 2 points - unsatisfactory; 3 to 4 points - regular; 5 to 7 points - satisfactory; and 8 to 9 points excellent.

\subsection{Statistical analysis:}

Statistical analysis used GraphPad Prism version 9.1 (GraphPad Software Inc., San Diego, United States). Descriptive statistics was performed using measures of frequency, central tendency and dispersion. Pie and bar charts were used to represent the distribution of the sample data. The Chi-square test was used to assess the distribution of categorical variables among the types of assessment instruments: questionnaire or photographs. The level of significance adopted was $5 \%$ for all tests.

\section{Results}

The sample consisted of 44 students, the majority (61.4\%) under the age of 25 and female (75\%). Although more than half of the interviewees $(68.2 \%)$ claimed to apply ergonomic principles during their clinical care, a substantial part (75\%) experienced frequent pain and $70.5 \%$ reported experiencing pain during and / or after dental treatment (Table 1).

Table 1. General characteristics of the the student sample.

\begin{tabular}{lcc}
\hline \multicolumn{1}{c}{ Variables } & n & \% \\
\hline Age group & & \\
< 25 years & 27 & 61.4 \\
25 to 30 years & 15 & 34.1 \\
$>$ 30 years & 2 & 4.5 \\
Sex & & \\
$\quad$ Female & 33 & 75.0 \\
Male & 11 & 25.0 \\
Report of frequent pain & 33 & 75.0 \\
Yes & 11 & 25.0 \\
No & & \\
Does your body hurt during or after clinical procedures? & 31 & 70.5 \\
Yes & 9 & 20.4 \\
No & 4 & 9.1 \\
Not applicable & & \\
Do you usually apply ergonomic principles during dental procedures? & 30 & 68.2 \\
Yes & 11 & 25.0 \\
No & 3 & 6.8 \\
\hline I do not know how to answer it & & \\
\hline
\end{tabular}

Source: Authors.

Among the students who reported frequent pain and discomfort, $46 \%$ reported pain 1 time per month, $30 \%$ said they feel pain more than 1 time per week, $15 \%$ more than once a month, $6 \%$ once a week and $3 \%$ daily (Figure 1). 
Figure 1. Distribution of the frequency of painful episodes among students who reported frequent pain.

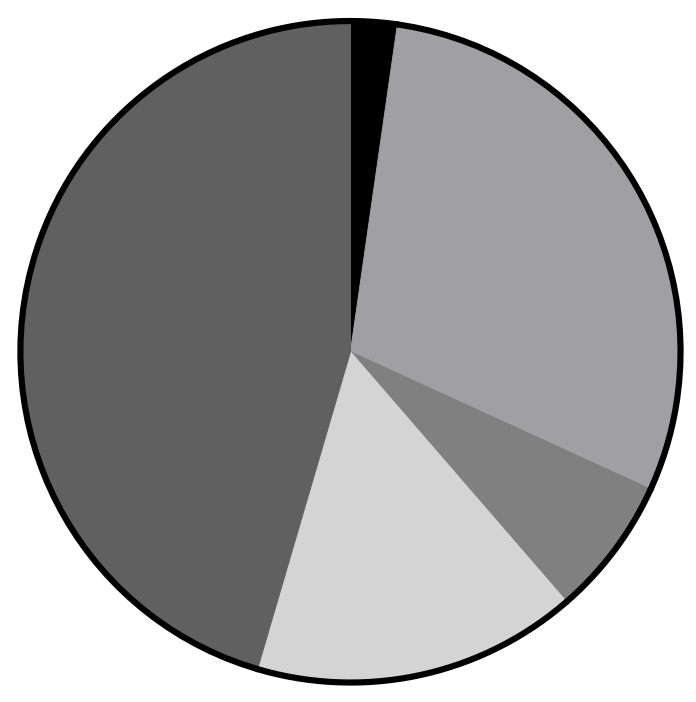

\section{$2.27 \%$ Daily \\ $\square$ 29.55\% More than 1 time per week $\square 6.82 \%$ Once a week \\ $\square 15.91 \%$ More than once a month $\square$ 45.45\% 1 time per month}

Regarding pain distribution by anatomical location, the results showed back trouble to be the most prevalent (61.4\%), followed by the neck (40.9\%), the head (27.3\%), legs (25\%), arms (20.5\%), eyes (11.4\%) and other sites (11.4\%) (Figure 2).

Figure 2. Distribution of reports of frequent pain by body parts.

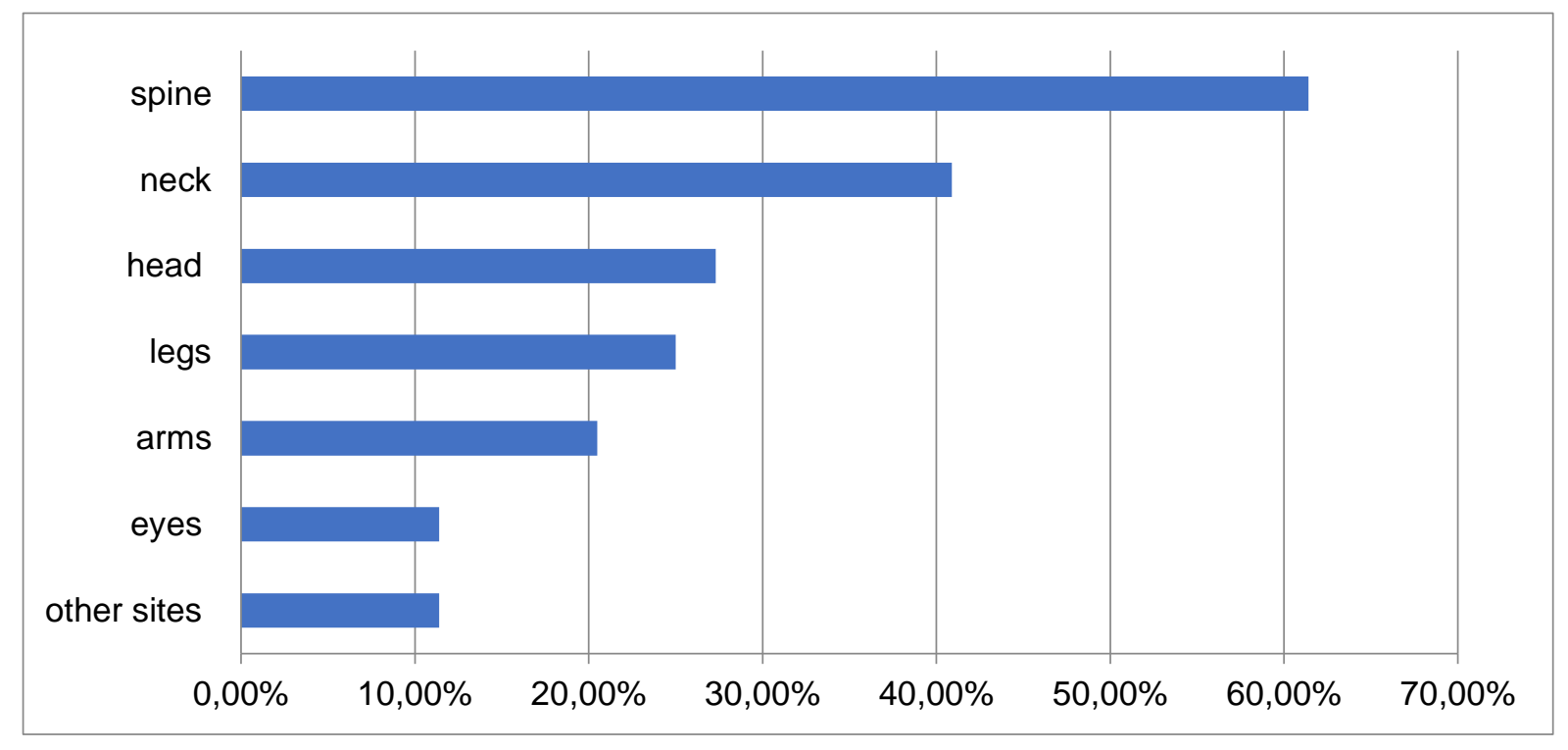

Source: Authors.

In terms of the classification of ergonomic posture adopted by students during dental practice, through the evaluation of photographic records, it was observed that $38.6 \%$ of students adopted satisfactory working posture and only $6.8 \%$ inappropriately (Table 2). 
Table 2. Classification of ergonomic posture by students according observation of the photographs taken during the clinical care.

\begin{tabular}{lccc}
\hline & Classification & n & \% \\
\hline Inappropriate & 3 & 6.8 \\
Regular & 12 & 27.3 \\
Satisfactory & 17 & 38.6 \\
Excelent & 12 & 27.3 \\
\hline TOTAL & 44 & 100.0 \\
\hline
\end{tabular}

Source: Authors.

Table 3 depicts the comparative analysis between participant's responses to the questionnaires and posture analysis observed during clinical practice. It can be seen that there were statistically significant differences $(\mathrm{P}<0.001)$ for lateral movements at the time of rendering dental treatment and position of the dental chair light beam. For the two situations, the position adopted during clinical practice showed better results. For the other positions, there was agreement between the responses to the questionnaires and the clinical application, having noticed poor positioning of the eyes and vertebral spine. Most of the participants showed a correct neck positioning in both assessments, but a significant number (47.7\%) of students performed a lateral neck tilt during clinical care.

Table 3. Comparative analysis between questionnaire evaluations and photographs.

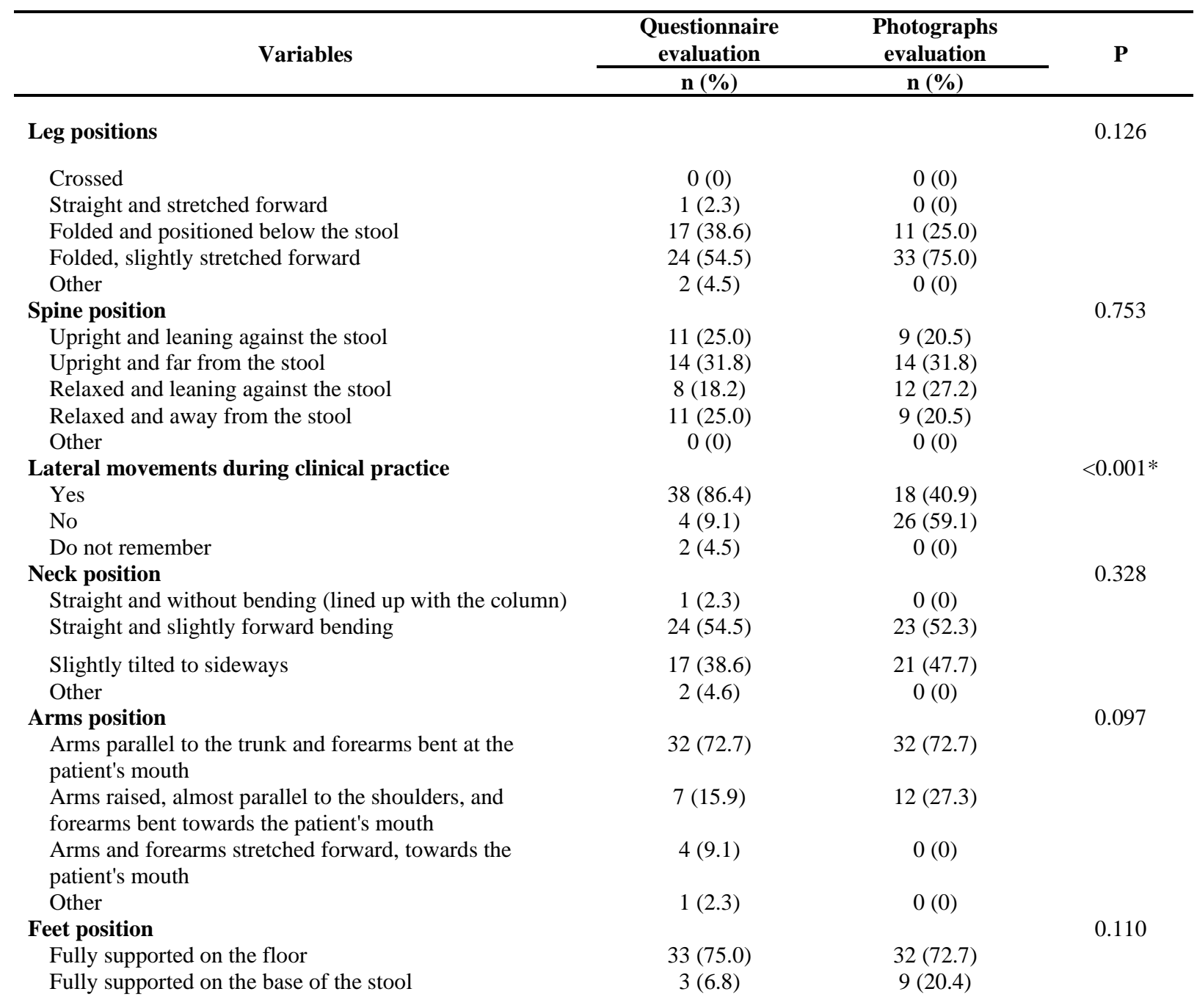




\begin{tabular}{|c|c|c|c|}
\hline $\begin{array}{l}\text { Toes resting on the floor and heel resting on the base of } \\
\text { the stool }\end{array}$ & $6(13.6)$ & $3(6.8)$ & \\
\hline Other & $2(4.6)$ & $0(0)$ & \\
\hline Eye's position & & & 0.456 \\
\hline $\begin{array}{l}\text { At a distance of approximately } 40 \mathrm{~cm} \text { from the patient's } \\
\text { mouth }\end{array}$ & $13(29.5)$ & $17(38.6)$ & \\
\hline $\begin{array}{l}\text { As close as possible, at a distance of approximately } 25 \mathrm{~cm} \\
\text { from the patient's mouth }\end{array}$ & $29(65.9)$ & $27(61.4)$ & \\
\hline $\begin{array}{l}\text { As far as possible, at a distance greater than } 50 \mathrm{~cm} \text { from } \\
\text { the patient's mouth }\end{array}$ & $1(2.3)$ & $0(0)$ & \\
\hline Other & $1(2.3)$ & $0(0)$ & \\
\hline Position of instruments & & & 0.589 \\
\hline At a distance of up to $50 \mathrm{~cm}$ from the body & $36(81.8)$ & $34(77.3)$ & \\
\hline At a distance between $50 \mathrm{~cm}$ and $1 \mathrm{~m}$ from the body & $7(15.9)$ & $7(15.9)$ & \\
\hline At a distance of more than $1 \mathrm{~m}$ from the body & $1(2.3)$ & $3(6.8)$ & \\
\hline Other & $0(0)$ & $0(0)$ & \\
\hline Dental chair beam of light position & & & $<0.001 *$ \\
\hline Parallel to the direction of observation & $8(18.2)$ & $40(90.9)$ & \\
\hline Obliquely to the observation direction & $9(20.4)$ & $3(6.8)$ & \\
\hline Perpendicular to the observation direction & $0(0)$ & $0(0)$ & \\
\hline Depending on the procedure performed & $27(61.4)$ & $0(0)$ & \\
\hline Other & $0(0)$ & $0(0)$ & \\
\hline
\end{tabular}

* Statistically significant differences through the chi-square test $(\mathrm{p}<0.05)$. Source: Authors.

\section{Discussion}

Ergonomics has been an ally in dentistry in terms of improving the work environment and reducing certain occupational musculoskeletal problems (Shobhana et al., 2020). Maintaining a proper posture would aid body in reducing its energy expense, improving the functioning of organs and it is protected against disturbances that can impair occupational practice (Garbin et al., 2011).

According to Oliveira et al. (2018), dental students are increasingly targets for developing disorders that affect both the muscular and the skeletal system, which can lead to extremely detrimental consequences in the future. This was evidenced in the present study, in which $75 \%$ of the participants reported experiencing frequent pain. Attention should be drawn to the fact that vast majority (95.5\%) of participants were up to 30 years of age. As many individuals usually ignore the potential risk factors, this process can extend over time, resulting in temporary or permanent early absence from work due to disability.

At the Federal University of Maranhao, Ergonomics is taught in the 2nd year of the academic course, a period in which clinical training also begin. With the incorporation of Ergonomics into curriculum, it is expected that the individual, since the inception of the course be concerned with adopting correct postures during consultations, using equipment and instruments that enhance their work within ergonomic principles (Saliba, 2016; Evelyn \& Jain, 2020).

It is known, however, that theoretical knowledge is not always sufficient in preventing work-related musculoskeletal disorders (Evelyn \& Jain, 2020). The applicability of ergonomics in dental preactice is essential for good health, both physical and mental. Although faculty members can intervene and provide ergonomic feedback, improvements may not be sustained if students are unaware or unwilling to adopt the ergonomic principles in routine dental practice (Partido, 2017).

Previous studies conducted demonstrate lack of knowledge on the topic, as well as frequent inappropriate postures during dental practicing (Harutunian et al., 2011; Khan, 2013). According to a study carried out in India by Bathan (2016) involving dentists and students, only $33.3 \%$ had previous knowledge about ergonomics, while nearly $38.7 \%$ had participated in any workshop on prevention of musculoskeletal disorders. In another study conducted in Malaysia, about 58\% of students reported that ergonomics had not been taught in their curriculum, while $93 \%$ of them had never participated in lectures on the 
prevention of musculoskeletal disorders in the dental school. The same percentage developed work-related musculoskeletal problems (Khan, 2013).

These data contrast with those found in the present study, in which $68.2 \%$ of the subjects reported applying ergonomic principles during their dental practice with patients, which was also confirmed by analysing the postures through photographs, in which $65.9 \%$ of students had adopted postures considered satisfactory or excellent.

On the other hand, although adequate postures were found in the vast majority of participants, $75 \%$ complained having frequently pain, among which $70.5 \%$ reported feeling during and/or after routine dental work. This survey, however, assessed only the position of students during dental procedures. It is known, however, that apart from work posture, other factors such as physical activity, levels of mental stress and work environment may contribute to the development of work-related musculoskeletal disorders (Mulimani, 2018), being important the development of future studies that assess these factors.

Furthermore, the clinical training for a fixed amount of time required by dental students is generally long, often lasting an entire shift, with no rests. According to a study by Khan (2013), only $20 \%$ of students reported exercising after clinical work, which is a key factor to prevent the onset of musculoskeletal disorders. The authors also concluded that students with long working hours at the clinic were 12 times more likely to report uneasiness in one or more regions of the body. According to Gupta et al. (2014), nearly 70 and $90 \%$ of dentists have recurrent episodes of pain, and one third of them continue to present recurrent or intermittent pain after the first episode. Hence, it is very important to identify ergonomic factors present in the dental workplace to prevent or reduce the risks of work musculoskeletal hazards.

Research has revealed that more than $70 \%$ of dental students have experienced neck, shoulders and lower back ache as early as the third year of dental practice (Rising et al., 2005). Literature review conducted by Mulimani (2018), the authors reported that the prevalence of back pain ranged from 22.2 to $91.0 \%$, neck pain from 20 to $84.9 \%$ and shoulder pain from 18.9 to $73.5 \%$. These data corroborate with those in the our study, in which $61.4 \%$ and $40.9 \%$ of the students reported feeling spine and neck pain, respectively.

The evaluations of this study revealed a scarcity of theoretical knowledge as well as poor positioning of the participants' spine and eyes, the latter positioned very close to the patient, leading to an excessive bending of the neck forward. In addition, though most of the students adopted fairly correct neck position in both evaluations (questionnaire and photographs), it was noticed that a significant number (47.7\%) of students tilted the neck sideways during clinical practice, which might justify the pains reported in these regions.

\section{Conclusion}

Overall, students evaluated had a sound knowledge towards ergonomic principles, as well as an adequate posture during routine dental procedures, but they did not put this into practice entirety, which may be related to the frequent discomfort reported by most of the interviewees.

It is therefore suggested that greater attention should be paid to dental graduates to implement the adoption of dental ergonomic principles throughout the course period, as well as the development of more studies on the subject. Such measures can significantly assist in reducing ergonomic-related heath disorders among these future professionals.

\section{References}

Ahearn D. J., Sanders M. J., \& Turcotle C. (2010). Ergonomic design for dental offices. Work, 35(4):495-503.

Batham, C., \& Yasobant, S. (2016). A risk assessment study on work-related musculoskeletal disorders among dentists in Bhopal, India. Indian J Dent Res, 27: 236-41. 
Bendezú, A., Nadia, V., Valencia, T. E., Aguilar, M., Luis, A., \& Vélez, F. C. (2006). Correlación entre nivel de conocimientos sobre posturas odontológicas ergonómicas, posturas de trabajo y dolor postural según zonas de respuesta, durante las prácticas clínicas de estudiantes en una Facultad de Estomatología. Rev. estomatol. Hered, 16(1): 26-32.

Evelyn, R. N., \& Jain, R. (2020). Work-related musculoskeletal disorders and ergonomic practices among dentists in Ludhiana. CHRISMED J Health Res, 7:1002 .

Garbin, A. J. Í., Garbin, C. A. S., Diniz, D. G., \& Yarid, S. D. (2011). Dental students' knowledge of ergonomic postural requirements and their application during clinical care. European Journal of Dental Education, 15(1):31-35.

Garcia, P. P. N. S, Campos J. A. D. B, \& Zuanon A. C. C. (2008). Clinical Evaluation of the Working Positions Adopted by Undergraduate Dental Students in the Pediatric Dentistry Clinic. Pesq Bras Odontoped Clin Integr, 8:31-7.

Garcia P. P. N. S, Gottardello A. C. A, Wajngarten D., Presoto C. D., \& Campos J. A. D. B. (2016). Ergonomics in dentistry: experiences of the practice by dental students. Eur J Dent Educ., 21 (3), 175-179.

Gopinadh A., Devi K. N., Chiramana S., Manne P., Sampath A., \& Babu M. S. (2013). Ergonomics and musculoskeletal disorder: as an occupational hazard in dentistry. J Contemp Dent Pract, 14(2):299-303.

Gupta A., Bhat M., Mohammed T., Bansal N., \& Gupta G. (2014). Ergonomics in dentistry. Int J Clin Pediatr Dent, 7 (1): $30-34$.

Hosseini, A., Choobineh, A., Razeghi, M., Pakshir, H. R., Ghaem, H., \& Vojud, M. (2019). Ergonomic Assessment of Exposure to Musculoskeletal Disorders Risk Factors among Dentists of Shiraz, Iran. Journal of dentistry (Shiraz, Iran), 20(1), 53-60.

Harutunian K, Gargallo-Albiol J, Figueiredo R, \& Gay-Escoda C. (2019). Ergonomic Assessment of Exposure to Musculoskeletal Disorders Risk Factors among Dentists of Shiraz, Iran. Journal of odontologia, 20(1): 53-60.

Kee D., \& Karwowski W. (2007). A comparison of three observational techniques for assessing postural loads in industry. Int J Occup Saf Ergon, 13(1):3-14.

Khan A. S., \& Chew K. Y. (2013). Effect of working characteristics and taught ergonomics on the prevalence of musculoskeletal disorders amongst dental students. BMC musculoskeletal disorders, 14(1):118.

Kumar S. P., Kumar V., \& Baliga M. (2012). Work-related musculoskeletal disorders among dental professionals: an evidencebased update. Indian Journal of Dental Education, 5(1):5-12.

Michalak-Turcotte C. (2000). Controlling dental hygiene work-related musculoskeletal disorders: the ergonomic process. $J$ Dent Hyg, 74(1): 41-8.

Movahhed T., Ajami B., Soltani M., Shakeri M. T. \& Dehghani M. (2013). Musculoskeletal pain reports among Mashhad dental students, Iran. Pak J Biol Sci, $16(2): 80-5$.

Mulimani P., Hoe V. C., Hayes M. J., Idiculla J. J., Abas A. B., \& Karanth L. (2018). Ergonomic interventions for preventing musculoskeletal disorders in dental care practitioners. Cochrane Database of Systematic Reviews, n. 10.

Oliveira, I. V. P. de, Braz, M. C. A., Urbano, S. C. F., Santos, Ítalo C. dos, \& Araki, Â. T. (2018). Conhecimento de alunos e professores sobre medidas ergonômicas. Arquivos Em Odontologia, 54. https://periodicos.ufmg.br/index.php/arquivosemodontologia/article/view/3769.

Partido, Brian B. (2017). Dental Hygiene Students' Self-Assessment of Ergonomics Utilizing Photography. Journal of dental education, 81(10): 1194-1202.

Rising D. W., Bennett B. C., Hursh K., \& Plesh O. (2005). Reports of body pain in a dental student population. J Am Dent Assoc, $136(1): 81-6$.

Sachdeva A, Bhateja S, \& Arora G. (2020). Ergonomics in dentistry: A comprehensive review. J Dent Res Rev, 7:32-5.

Shobhana R., Geethapriya N., Mary N. S. G. P., \& Tamilselvi R. (2020). Ergonomics in dentistry to enhance work efficiency. JCR, 7(14): 3423-26

Wilson E. L., Madigan M. L., Davidson B. S., \& Nussbaum M. A. (2006). Postural strategy changes with fatigue of the lumbar extensor muscles. Gait Posture, 23(3): 348-54. 